\title{
Problems and countermeasures in reformation of old urban residence XiuHua.LI ${ }^{1, \mathrm{a}}$, ChenXi.YUE ${ }^{1, \mathrm{~b}}$ and JianXiong.LIU ${ }^{1, \mathrm{c}}$ \\ ${ }^{1}$ Department of Architectural Engineering, HuaiYin Institute of Technology, Huaian, China \\ alixiuhuayou@163.com, bycxmail@163.com, Cliujianxiong@163.com
}

\begin{abstract}
Keywords: Problem; Countermeasure; Reformation; Old urban residence
Abstract. With the improvement of living standards of urban, old residential facilities have been behind the times, the people's desire to enjoy a better life is more intense. Remediation of the old urban residence is the requirement to create a civilized city and ecological city, is the requirement to build a moderately prosperous society. Article discusses the problems of the old urban residence and the necessity of the transformation, gives the recommendations and measures, has some significance for the transformation of the old urban residence.
\end{abstract}

\section{Introduction}

Currently, the definition of old urban residence all over the country is slightly different, but generally refers to those design and construction of the early construction of low standard, supporting incomplete, outdated equipment aging, poor management, poor human environment of the old residential quarters. Usually built before the 1990s, a large proportion of cells in the city.

\section{Importance and Necessity}

To enhance management of urban. Due to the limitations of history, these old residential quarters in terms of planning public facilities design, construction standards, or in terms of management, operation mechanism, can not meet the growing demand for residential housing capital. Especially with the reform, the old residential quarters of the housing system is formed gradually diversified ownership, maintenance and management of community funding sources gradually dried up, reducing the level of management, management function degradation, resulting in the formation of the old residential quarters of people living environment and new residential environments strong contrast, has become the urban construction and management of the backward areas.

To improve people's livelihood. Most of old urban residence congenitally malnutrition, leading to district residents face many problems in daily life and practicaldifficulties. For example, the district road maintenance deficiencies, road potholes, missing streetlights, affecting residents travel; creating a safety hazard; water pipes around the house damaged, congested, basic loss Urban Flood Control function, the inconvenience to residents. Residents of the old district eager to change this situation as soon as possible. To solve these problems, the urgent need for a comprehensive renovation cells, efforts to improve the living and environmental conditions used, and establish a sound mechanism for regular and orderly management, to form a cell to maintain a virtuous cycle management. From the old district comprehensive improvement in recent years and introduced a standardized management, the masses well, community residents thanked the government to solve the common people most concerned about, the most direct and most practical real life problems and improve the the people's living environment and improve the quality of life of the people, for the people to do practical things, to do something good.

To build a harmonious community. A safe and beautiful, harmonious and comfortable living space for the formation of harmonious interpersonal relationships, maintain social stability and unity has a very important role. Old district comprehensive improvement goals , the first is not the pursuit of economic efficiency, but efforts to seek a unified social, environmental and economic benefits. Significance lies not only in a simple comprehensive treatment to improve and maintain community order, guarantee the basic living conditions of households, but also in relation to coordinate all aspects of the community, and resolve imbalances, social 
conflicts caused by disharmony factors, maintaining social stability, and create a harmonious cultural environment.

To show a good image of the city. Residential areas are the cells. With the accelerated pace of the city, a batch of a beautiful environment, complete functions, advanced management of new residential areas have sprung up, giving residents bring a strong visual impact and psychological feelings, has become a showcase of urban construction and management the level of an important window. However, some pales compared to the old district, the old district of "dirty, chaotic, and poor" condition, even to some extent, seriously affect the city's image. So to speak, not the face of the old residential quarters live fundamentally changed the content and enhance the overall image of the city is just empty talk.

\section{Old Residential District Management Status}

Infrastructure obsolescence, without the system maintenance and repair. That is the old district are to the "issue phase", such as housing stucco surface weathering from the shell; staircase handrail off the corridor walls rust, no public lighting; water pipes around the house damaged, clogged rain, septic tank being cleaned regularly; aging residential roads, no street lights or pavement damage; green weeds, confusing layout and some parkland or even be used to grow vegetables. Low standard fire control system design, high-rise elevator building high-rise buildings, no dedicated fire pump and fire control cabinet, fire facilities natural damage, vandalism and theft is serious, cause great fire safety hazards.

Living environment is dirty and chaotic. Mainly in all kinds of illegal structures, unlicensed stalls, car parking chaos, it has become a chronic disease affecting urban appearance. Almost every old residential quarters have illegal buildings, some of the individuals, units, streets without the planning department permission, on both sides of the main road in the district chaotic ride pavilion roof, the affected cell traffic and landscape, destruction of residential green, shown in Figure 1 and Figure 2.Motor vehicles, bicycles parked disordered, random occupation pavement, causing traffic congestion. Old residential buildings tend to be more scattered, difficult to achieve relatively closed and independent, anyone can freely access; some cell walls and the absence of guard duty room, vehicle theft and criminal cases have occurred, there is a big security risk. The old residential quarters, due to various reasons, rental rates are generally higher, residential staff and foreign population.

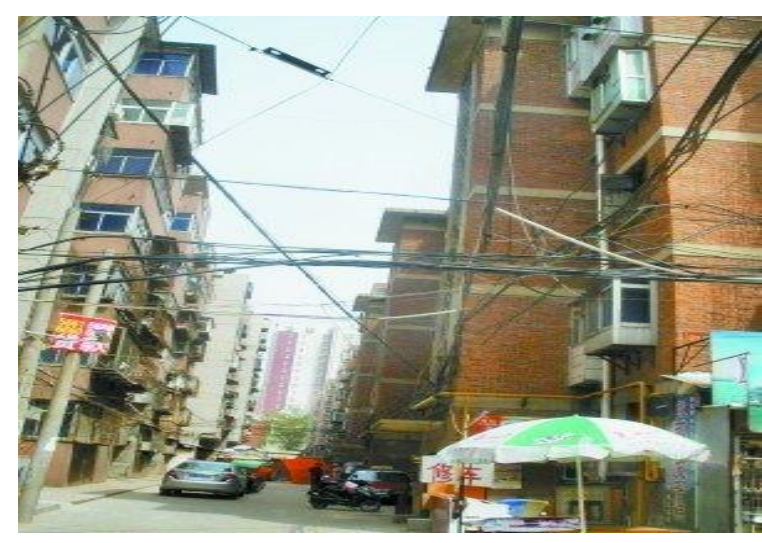

Figure 1 Chaos of the wire in old urban residence

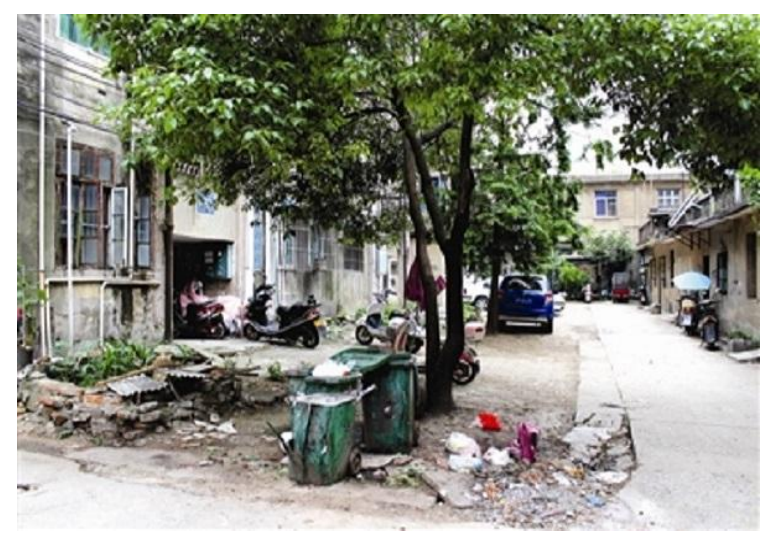

Figure 2 Scattered garbage in old urban residence

The lack of public facilities. Some old residential quarters, beginning of the construction, but in order to solve the housing difficulties of the residents, planning is relatively simple. Contradictions resident activities, public green space, bicycle storage, parking and other facilities and people's actual needs are quite prominent, sanitation facilities are not complete, and some do not trash and garbage transfer stations, garbage rooms, toilets, etc. Fruit Housing Box set too less, in some places even a blank. Most existing public facilities district plan allocation ratio is low, only a few public facilities and some have been diverted to other purposes, some 
of the residential neighborhood houses have been rented or sold to other units, residential neighborhood with the relationship between property management companies do not and fight for housing, struggle for power, contradictions. The municipal government has increased investment in transformation efforts, some of the old residential quarters conditions have improved, but these problems have not been fundamentally resolved.

\section{Some Issues to be Solved}

Forming remediation force. Remediation tasks involving heavy renovation of the old district, a wide range of content, involving construction, planning, business, urban management, housing, streets, water, running water, and more than a dozen government departments or units. Or in the renovation of inputs alone individual departments is difficult to undertake this task both in terms of remediation work must be an union, to participate, a clear division of tasks and responsibilities, close coordination and work together to ensure that the old promote a strong community rectification work.

Financing of the renovation funds. Urban old district and more funding remediation tens billion. If borne entirely by the government or department, government will not afford, if borne by the enterprise, is neither realistic nor reasonable. Because the propulsion system coupled with the housing reform, the residential property had diversified, and therefore, can not be grabbed development unit or hold the original property unit, it should be based on looking for funding in the cell, the maximum extent possible, to maximize the rational utilization of idle land plot or secondary development of substandard housing, not in government and business investment, does not affect the planning, the realization of financial balance. Notched part of the funds can not be balanced, then by the house owner, original house property units, housing construction, government and government departments by a certain percentage apportion more appropriate.

Improving the follow-up management. Let the residents know, housing property has diversified, as the property owner to assume responsibility for repair and maintenance. Only through the establishment of autonomous organizations and other owners' committee, complete renovation of old residential quarters supervision and follow-up management, in order to truly safeguard their own interests, long-term management of the implementation mechanism. Meanwhile, to make the majority of streets, community leaders know, the old residential area of repair and maintenance and other management services should also be transformed into government action past market behavior, to transform government functions, and gradually change the role, and actively do to abdicate and make up bit operation, the complete renovation of the old residential quarters subsequent management giving way to social, market-oriented, professional property management, and strengthen supervision and management. Otherwise, the remediation results will come to naught.

\section{Countermeasures}

Government plays a lead. In accordance with the principle of government organizations, neighborhood participation, local conditions, and actively carry out repair and maintenance of buildings, supporting facilities, to extend the service life of buildings, improve housing conditions. Renovation of old residential quarters each year by the district (county) to propose a plan, budgeting and organizing street (township) implementation. To further increase investment, the allocation of funds to ensure the remediation funding; at the same time, we should actively introduce market mechanisms to mobilize social capital strength to participate in the old residential quarters remediation.

Multiple departmental regulation. Comprehensive renovation of old residential quarters involves a wide range funding gap, is a matter of global complex and difficult systems engineering. Municipal levels of government, the district should play a leading role, led the establishment of a permanent governing body remediation work relevant functional departments to participate, as the comprehensive improvement of the urban permanent offices at all levels. Establish the appropriate mechanism to clarify their respective responsibilities, to develop the overall renovation plan, to study the implementation,renovation financing, 
residential hardware facilities, and other important matters to address progress in emerging difficulties and problems, to ensure that the old district comprehensive improvement smoothly.

To establish a long-term management mechanism. In the management mode, according to the comprehensive renovation after the principle of housing, the environment, facilities, owners or users of affordability, as well as property management in line with the actual needs of the old district according to the actual situation, and respect the wishes of the residents, different circumstances and characteristics of the cell, flexible and diverse follow-up management model to promote a virtuous circle of old residential management. For the facilities are relatively independent, more perfect, has a certain scale of the old district, you can take organized meeting of owners and the owners' committee elections, according to selection of property companies, were the property of the community service. For the introduction of property companies do not have the conditions of service of the cell, may be made on behalf of the community neighborhood residents, according to the houses and facilities and equipment maintenance, cleaning, security and other professional service companies signed entrust management and service contracts, professional services firm providing service in accordance with the terms of the contract and remunerated.

To improve related policies and regulations. For the new district, there are a variety of national and local construction and management laws and regulations; but the old district comprehensive improvement and ongoing management of the country are no specific laws and regulations and management practices. From all over the country in recent years, the comprehensive renovation of old residential quarters of experiences and lessons, the old residential quarters comprehensive treatment, is also facing heavy resistance around similar and difficult. To effectively safeguard the legitimate rights and interests of the owners, the promotion of social, market-oriented, professional management mechanism to establish the old district, only strengthen the legal and policy constraints to ensure that the old residential renovation work, especially vacate facilities and repurchase and smoothly up building work, in order to consolidate the results of rectification, the old district municipal government to expand social remediation work.

\section{Summary}

The old district comprehensive improvement is not simply a short-term assault several departments work will achieve their goals, it is not simply to be a temporary fix for the cell appearance, but the old residentialquarters live orderly and habitat restoration and reconstruction. Such an integrated system renovation project, supporting the need to develop appropriate policies and regulatory documents to be regulated, the need to develop appropriate complete thorough scientific remediation program but the need to establish a unified command and coordination management mechanism in order to effectively promote .Through comprehensive treatment of the old district, the "old district" into one unique environment of a beautiful, comfortable and convenient, safe and civilized and harmonious community, build a happy home residents.

\section{References}

[1] Qi-ang sun: submitted to Journal of nanjing university of technology, China (2010)

[2] Hu Yiping: submitted to Journal of China's property management, China (2009)

[3] Ting-ting lu: submitted to Journal of Modern property, China (2008)

[4] Zhigang wang,: submitted to Journal of Modern property, China (2007)

[5] Angel,S.and Am,P: submitted to Journal of Habitat International .Thailand (2009) 